\title{
Liquidity Supervision in Financially Viable Sector with Reference to Public and Private Sector Banks in India
}

\author{
Gokul G. ${ }^{1}$, M. R. Ranganatha ${ }^{2}$ \\ ${ }^{1}$ Department of Management Studies, the Oxford College of Engineering, Bangalore, India \\ ${ }^{2}$ Department of Management Studies, Don Bosco Institute of Management Studies and Computer Applications, Bangalore, India
}

Email address:

goku14edge@gmail.com (Gokul G.),magadi2010@gmail.com (M. R. Ranganatha)

\section{To cite this article:}

Gokul G., M. R. Ranganatha. Liquidity Supervision in Financially Viable Sector with Reference to Public and Private Sector Banks in India. International Journal of Finance and Banking Research. Vol. 3, No. 2, 2017, pp. 34-38. doi: 10.11648/j.ijfbr.20170302.12

Received: April 16, 2016; Accepted: February 25, 2017; Published: May 10, 2017

\begin{abstract}
Liquidity risk in Indian banking sector is strongly influenced by structural and business cycle factors over many years. Sudden change in technological development and market globalization has posed serious challenge to the Indian banks to manage liquidity. The deposit collections made were not able to keep up with the sudden loan growth. This paper summarizes the theoretical findings on the determinants of Liquidity Management by banks. The findings are summarized in a series of predictions.
\end{abstract}

Keywords: Liquidity, Demand Deposits, Term Deposits, Money at Call \& Short Notice

\section{Introduction}

Liquidity Supervisionmeasures the ability of Financial Intermediary to meet demand for deposits, withdrawal and other cash outflows. Financial Intermediaries are those middle men who transact in financial instruments between two parties. Banks are typical Financial Intermediaries; it also includes Investment banks, Insurance companies, mutual funds, brokers, dealers and pension funds. Public sector banks are those banks whose majority of stake is held by the Government and even the Private sector the shares of these banks are listed in stock exchanges. In India, there are 26 public sector banks. As we all know, these financial intermediaries are large players in the money and security market and if the liquidity management of these financial intermediaries fails, a lack of confidence prevails in the economy which leads to intolerable inflation. If the Government monetary policies fail to curb inflation, then it weakens the economic growth and development in any country. In this paper, an attempt in made to explain why such crises arise and how to overcome or minimize such occurrences.

\subsection{Objectives}

- To study the current position of liquidity Management in banking sector
- To study the tools applied by banks for measuring liquidity as prescribed by the regulatory authority are effective or not.

- To identify measures to reduce liquidity position from the current status.

\subsection{Need for Study}

Whenever an economy passes from one stage to another, the economic condition changes its macro and micro situations, which affects the economic progress of a nation and there is a need for correction in the market scenario. The success and failure of market scenarios depend upon many factors including those related to policy, supply side constraints and macro economics condition. Out of this, liquidity management is one of the important factors that play its role in the correction of macroeconomic condition. Now India is facing the same situation and around the globe each and every economy is passing through the same stage. The need of the hour is to call for correction of liquidity management at large.

On rupee and FCNRB (Foreign Currency Non-Resident Banking) front, the RBI (Reserve Bank of India) raised rupee rate to $8 \%$, it took a long time to raise FCNRB by RBI and by the time rupee rate was raised by $8-9 \%$. The exposure rate of risk between the domestic rate and NRI got contracted. 
That is why we are seeing relatively slow dollar flow. If proper adjustment is made in the monetary and economic policy, then these payments can be recovered with fewer hurdles and further, these payments can be used for cushioning economic risk. The top contender to lead the Federal Reserve Ms. Janet Yallen* has said in her statement that the financial crisis in US led her to believe that regulators had too much discretion and the regulatory system needs to be tightened.

The Finance service secretary Rajiv Takur**,in a statement to the industrialist and bankers, told in Mumbai on Wednesday August 13, 2013

"If you are a willful defaulter you are going to lose control of your company and certain section of people who rejoice when the system is in financial distress are to be taken care of."

The message given by these people shows that mismanagement by banks in lending the loan to the corporate is crumbling liquidity management. Therefore, it is essential to study the components of Liquidity management such as Liquid assets to total assets, G-secs to total assets, Liquid assets to demand deposits and liquid assets to total deposits ratio behavior from 2011 to 2015 .

\subsection{Review Literature}

Liquidity Management is a central theory for all Financial Intermediaries. Equity capital plays an important role in Liquidity function of commercial banks.Diamond and Rajan (2000) said equity capital can act as a buffer to protect depositors in the time of distress But holding excessive equity capital can reduce Liquidity. Beger \& Bouwman(2010) explained that higher level of capital out of depositors reduces the liquidity creation at small banks. Sambhav Garg, Priya Jindal \& Dr.Bhavet (2013)in their paper emphasized that banks run on confidence and trust. Confidence enjoyed banks enable them to mobilize the dormant funds of public and make them available for productive purpose. Guillermo Alger \& Ingda Alger (1999) determined that Banks with relatively more demand deposits have relatively less liquid assets. Karthik Srinivasan \& Vineet Gupta (2007) stated that with the splurge in the credit off-take, banks have to increase their reliance on bulk funding short term sources.At the same time many of them have also been pairing their excess statutory Liquid ratio (SLR) portfolio to fund the credit growth.

\section{Methodology}

In this study, Analytical research methodology is used which determines the liquidity of the sample companies through accurate and complete analysis of their past records.

\subsection{Sampling Design}

A sample design is a definite plan for obtaining a sample from a given population. The samples are chosen based on the market capitalization. The data required for the study were collected from annual reports of the companies.

\subsection{Research Tools}

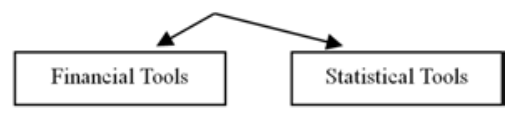

\subsubsection{Financial Tools}

CAMEL is basically a ratio-based model for evaluating the performance of banks. The various ratios forming this model are.

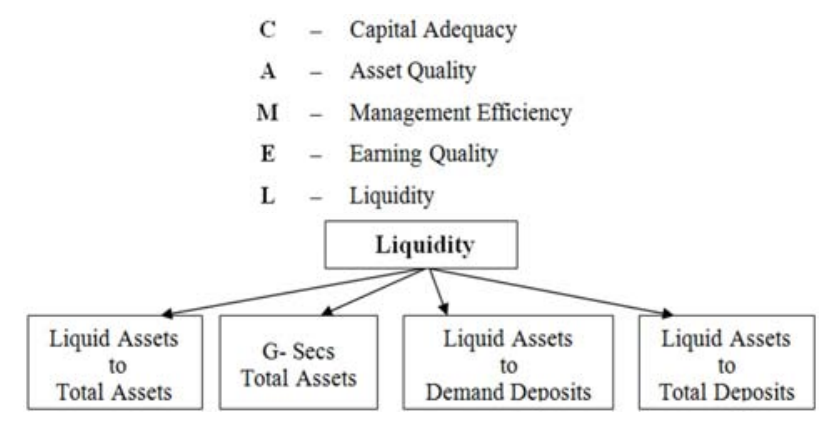

\subsubsection{Statistical Tools}

Mean and standard deviation is determined to compare the relationship of different variable of every company

\subsection{Data Processing and Tabulations}

After completion of the data collection, MS-Excel was used to analyze the data. The accuracy of the data entry was rechecked to ensure error-free database.

\subsection{Liquid Assets to Total Assets}

The ratio of liquid assets to total assets position of sample companies is presented in table 1 .

Table 1. Liquid Assets to Total Assets (in\%) of sample companies.

\begin{tabular}{|c|c|c|c|c|c|c|c|c|c|c|c|}
\hline \multirow{2}{*}{$\frac{\text { Bank } \rightarrow}{\text { Years } \downarrow}$} & \multicolumn{5}{|c|}{ (a) Public Sector Banks } & \multicolumn{5}{|c|}{ (b) Private Sector Banks } & \multirow{2}{*}{$\begin{array}{l}\text { Industry } \\
\text { Average }\end{array}$} \\
\hline & SB & SBM & SBI & Vijaya & AVG & ING & YES & KB & HDFC & AVG & \\
\hline 2011 & 8.55 & 8.78 & 7.92 & 9.78 & 8.76 & 7.71 & 13.98 & 6.45 & 7.39 & 8.88 & 8.82 \\
\hline 2012 & 9.02 & 17.07 & 10.19 & 11.87 & 12.04 & 6.78 & 7.32 & 5.82 & 8.4 & 7.08 & 9.56 \\
\hline 2013 & 9.17 & 9.63 & 12.29 & 12.77 & 10.97 & 10.77 & 9.44 & 4.12 & 12.4 & 9.18 & 10.07 \\
\hline 2014 & 9.35 & 9.46 & 9.01 & 12.42 & 10.06 & 9.52 & 11.41 & 4.46 & 9.36 & 8.69 & 9.37 \\
\hline 2015 & 9.58 & 10.06 & 11.16 & 13.01 & 10.95 & 9.98 & 11.9 & 5.06 & 10.43 & 9.34 & 10.15 \\
\hline Mean & 9.13 & 11.00 & 10.11 & 11.97 & 10.55 & 8.95 & 10.81 & 5.18 & 9.60 & 8.64 & 9.59 \\
\hline SD & 0.35 & 3.06 & 1.54 & 1.16 & 1.10 & 1.48 & 2.27 & 0.86 & 1.73 & 0.81 & 0.49 \\
\hline
\end{tabular}

Source: Workings has been performed in MS-EXCEL from the data available in annual reports of the companies concerned 
As it could be observed in Table 1(a) among all the sample companies of public sector banks, the ratio of liquid assets to total assets varied between the highest of $12.04 \%$ in 2012 and the lowest of $8.76 \%$ is 2011 . On overall basis, the liquid assets to total assets was sufficient $(10.55 \%)$ across the industry. Of all the companies, Vijaya Bank had more liquid assets to total assets than the yearly industry averages in every year.

As it could be observed in Table - 1(b) among all the sample companies of private sector banks, the ratio of liquid assets to total assets varied between the highest of $9.34 \%$ in 2015 and the lowest of $7.08 \%$ in 2012 . On overall basis, the liquid assets to total assets was sufficient (8.64\%) across the industry. Of all the companies, Yes Bank had more liquid assets to total assets than the yearly industry averages in every year.

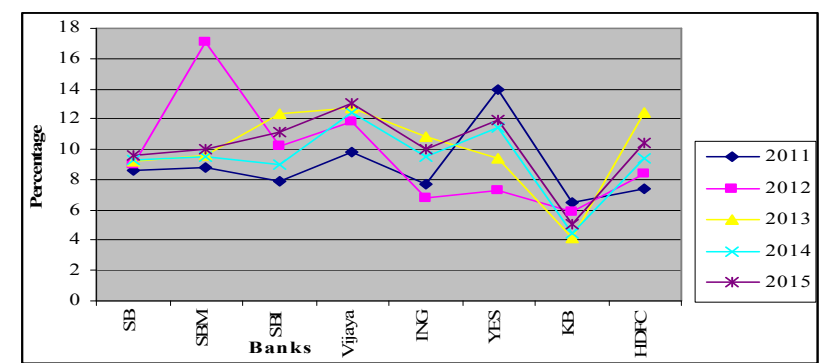

Figure 1. Indicates Liquid Assets to Total Assets of all sample companies.

\subsection{Government Securities to Total Assets}

The ratio of G-secs to total assets position of sample companies is presented in table 2 .

Table 2. Government Securities to Total Assets (in\%) of sample companies.

\begin{tabular}{|c|c|c|c|c|c|c|c|c|c|c|c|}
\hline \multirow{2}{*}{$\begin{array}{l}\text { Bank } \rightarrow \\
\text { Years } \downarrow\end{array}$} & \multicolumn{5}{|c|}{ (a) Public Sector Banks } & \multicolumn{5}{|c|}{ (b) Private Sector Banks } & \multirow{2}{*}{$\begin{array}{l}\text { Industry } \\
\text { Average }\end{array}$} \\
\hline & SB & SBM & SBI & Vijaya & AVG & ING & YES & KB & HDFC & AVG & \\
\hline 2011 & 37.39 & 32.63 & 21.39 & 30.64 & 30.51 & 20.57 & 19.97 & 20.41 & 21.8 & 20.69 & 25.60 \\
\hline 2012 & 27.39 & 23.01 & 20.6 & 22.93 & 23.48 & 20.37 & 23.71 & 23.31 & 26.01 & 23.35 & 23.42 \\
\hline 2013 & 20.88 & 22.55 & 18.22 & 18.34 & 20.00 & 19.63 & 22.44 & 24.01 & 23.17 & 22.31 & 21.16 \\
\hline 2014 & 19.56 & 22.22 & 19.17 & 19.08 & 20.01 & 18.85 & 18.42 & 26.71 & 23.37 & 21.84 & 20.92 \\
\hline 2015 & 19.05 & 23.01 & 19.56 & 18.76 & 20.10 & 18.03 & 19.08 & 27.8 & 24.26 & 22.29 & 21.19 \\
\hline Mean & 24.85 & 24.68 & 19.79 & 21.95 & 22.82 & 19.49 & 20.72 & 24.45 & 23.72 & 22.10 & 22.46 \\
\hline
\end{tabular}

Source: Workings has been performed in MS-EXCEL from the data available in annual reports of the companies concerned

As it could be observed in Table - 2(a) among all the sample companies of public sector banks, the ratio of G-secs to total assets varied between the highest of $30.51 \%$ in 2011 and the lowest of $20 \%$ is 2013 . On overall basis, the G-secs to total assets was sufficient (22.82\%) across the industry. Of all the companies, Syndicate Bank had more G-secs to total assets than the yearly industry averages in every year.

As it could be observed in Table - 2(b) among all the sample companies of private sector banks, the ratio of G-secs to total assets varied between the highest of $23.35 \%$ in 2012 and the lowest of $20.69 \%$ in 2011 . On overall basis, the Gsecs to total assets was sufficient $(22.10 \%)$ across the industry. Of all the companies, Karnataka Bank had more Gsecs to total assets than the yearly industry averages in every year.

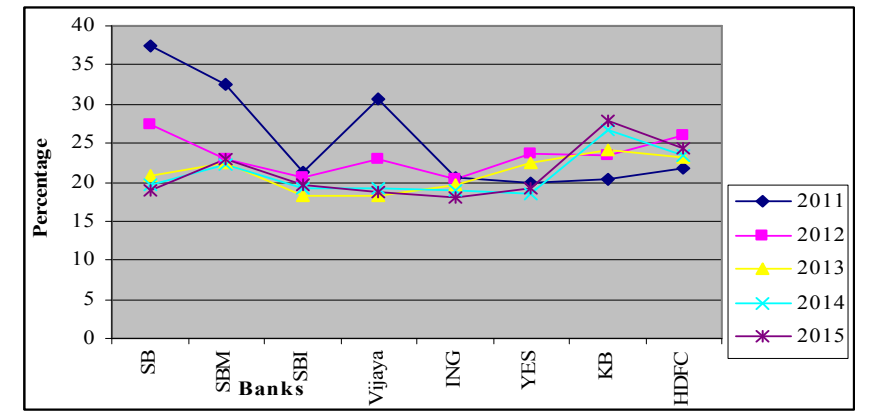

Figure 2. Government Securities to Total Assets of all sample companies.

\subsection{Liquid Assets to Demand Deposits}

The ratio of liquid assets to demand deposits position of sample companies is presented in table 3 .

Table 3. Liquid Assets to Demand Deposits (in\%) of sample companies.

\begin{tabular}{|c|c|c|c|c|c|c|c|c|c|c|c|}
\hline \multirow{2}{*}{$\begin{array}{l}\text { Bank } \rightarrow \\
\text { Years } \downarrow\end{array}$} & \multicolumn{5}{|c|}{ (a) Public Sector Banks } & \multicolumn{5}{|c|}{ (b) Private Sector Banks } & \multirow{2}{*}{$\begin{array}{l}\text { Industry } \\
\text { Average }\end{array}$} \\
\hline & SB & SBM & SBI & Vijaya & AVG & ING & YES & KB & HDFC & AVG & \\
\hline 2011 & 69.46 & 88.95 & 123.43 & 134.68 & 104.13 & 100.73 & 73.74 & 10.82 & 129.23 & 78.63 & 91.38 \\
\hline 2012 & 65.53 & 148.24 & 154.54 & 160.58 & 132.22 & 102.82 & 45.69 & 78.1 & 123.21 & 87.46 & 109.84 \\
\hline 2013 & 63.38 & 95.02 & 185.84 & 185.12 & 132.34 & 173.66 & 61.2 & 79.14 & 151.66 & 116.42 & 124.38 \\
\hline 2014 & 68.75 & 105.84 & 142.05 & 190.66 & 126.83 & 154.07 & 62.38 & 81.06 & 120.87 & 104.60 & 115.71 \\
\hline 2015 & 70.06 & 113.26 & 137.09 & 201.05 & 130.37 & 143.03 & 63.01 & 82.02 & 121.1 & 102.29 & 116.33 \\
\hline Mean & 67.44 & 110.26 & 148.59 & 174.42 & 125.18 & 134.86 & 61.20 & 66.23 & 129.21 & 97.88 & 111.53 \\
\hline
\end{tabular}

Source: Workings has been performed in MS-EXCEL from the data available in annual reports of the companies concerned 
As it could be observed in Table - 3(a) among all the sample companies of public sector banks, the ratio of liquid assets to demand deposits varied between the highest of $132.34 \%$ in 2013 and the lowest of $104.13 \%$ is 2011 . On overall basis, the liquid assets to demand deposits was sufficient $(125.18 \%)$ across the industry. Of all the companies, Vijaya Bank had more liquid assets to demand deposits than the yearly industry averages in every year.

As it could be observed in Table - 3(b) among all the sample companies of private sector banks, the ratio of liquid assets to demand deposits varied between the highest of $116.42 \%$ in 2013 and the lowest of $78.63 \%$ in 2011 . On overall basis, the liquid assets to demand deposits was sufficient (97.88\%) across the industry. Of all the companies, ING Visya Bank had more liquid assets to demand deposits than the yearly industry averages in every year.

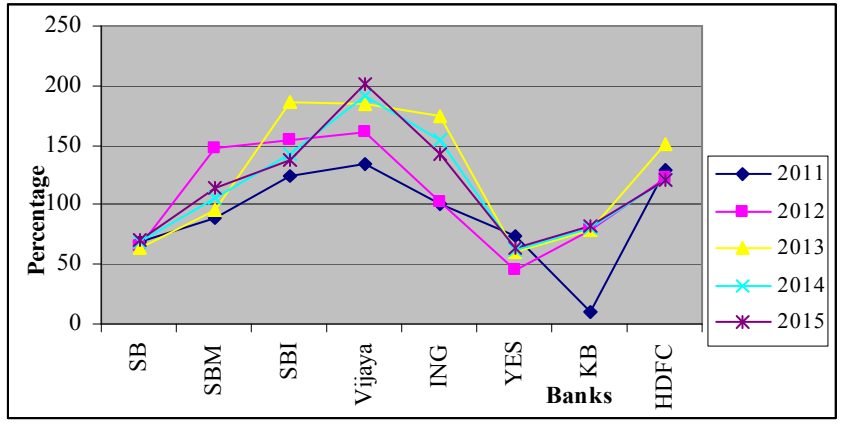

Figure 3. Liquid Assets to Demand Deposits of all sample companies.

\subsection{Liquid Assets to Total Deposits}

The ratio of liquid assets to total deposits position of sample companies is presented in table 4.

Table 4. Liquid Assets to Total Deposits (in\%) of sample companies.

\begin{tabular}{|c|c|c|c|c|c|c|c|c|c|c|c|}
\hline \multirow{2}{*}{$\begin{array}{l}\text { Bank } \rightarrow \\
\text { Years } \downarrow\end{array}$} & \multicolumn{5}{|c|}{ (a) Public Sector Banks } & \multicolumn{5}{|c|}{ (b) Private Sector Banks } & \multirow{2}{*}{$\begin{array}{l}\text { Industry } \\
\text { Average }\end{array}$} \\
\hline & SB & SBM & SBI & Vijaya & AVG & ING & YES & KB & HDFC & AVG & \\
\hline 2011 & 10.71 & 10.75 & 9.55 & 11.38 & 10.60 & 12.95 & 16.64 & 11.17 & 8.8 & 12.39 & 11.49 \\
\hline 2012 & 11.72 & 20.71 & 12.19 & 14.37 & 14.75 & 10.32 & 9.08 & 11.14 & 9.87 & 10.10 & 12.43 \\
\hline 2014 & 12.55 & 11.31 & 11.81 & 14.67 & 12.59 & 15.56 & 14.27 & 12.47 & 11.44 & 13.44 & 13.01 \\
\hline 2015 & 13.01 & 12.7 & 10.9 & 14.58 & 12.80 & 14.6 & 16.02 & 12.98 & 11.08 & 13.67 & 13.23 \\
\hline Mean & 11.98 & 13.33 & 11.79 & 13.93 & 12.76 & 13.91 & 13.56 & 11.95 & 11.18 & 12.65 & 12.70 \\
\hline
\end{tabular}

Source: Workings has been performed in MS-EXCEL from the data available in annual reports of the companies concerned

As it could be observed in Table - 4(a) among all the sample companies of public sector banks, the ratio of liquid assets to total deposits varied between the highest of $14.75 \%$ in 2012 and the lowest of $10.60 \%$ is 2011 . On overall basis, the liquid assets to total deposits was sufficient (12.76\%) across the industry. Of all the companies, Vijaya Bank had more liquid assets to total deposits than the yearly industry averages in every year.

As it could be observed in Table - 4(b) among all the sample companies of private sector banks, the ratio of liquid assets to total deposits varied between the highest of $13.67 \%$ in 2015 and the lowest of $10.10 \%$ in 2012 . On overall basis, the liquid assets to total deposits was sufficient (12.65\%) across the industry. Of all the companies, ING Visya Bank had more liquid assets to total deposits than the yearly industry averages in every year

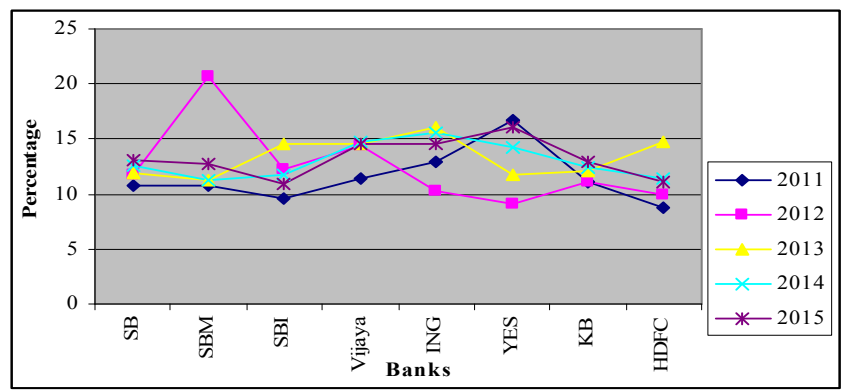

Figure 4. Liquid Assets to Total Deposits of all sample companies.

\section{Findings}

Based on the values derived through calculations, suitable findings and conclusions were arrived at for every company and for every measure of financial ratios. In addition, suitable suggestions were made to enhance efficiency of Liquidity position in the selected company.

- The liquid assets to total assets is very high with Vijaya Bank(11.97\%) which indicates more liquidity position and very low with Karnataka Bank (5.18\%).

- G-sec to Total Assets is very high in terms of Syndicate Bank (24.85\%) which indicates more liquidity position and very low in terms of State Bank of India (19.79\%).

- The liquid asset to Demand Deposits is very high with Vijaya Bank (174.42\%) which indicates more liquidity available in terms of demand deposits and very low with Yes Bank (61.20\%).

- The liquid assets to total deposits is very high with Vijaya Bank (13.93\%) which indicates more liquidity available in terms of total deposits and very low with HDFC Bank (11.18\%).

\section{Suggestions}

- The private sector banks should plan to increase the liquidity position when compared to public sector 
banks, in general........

- They should accept more deposits in the future by offering more benefits to the customers in terms of fixed deposits, term deposits and also to concentrate on the urban part of India so that banks can sustain in the future.

\section{Conclusion}

The financial performance plays a significant role in the successful functioning of a firm. The attempt has been made in the present study to have an insight into the examination of liquidity position of the banking industry in India. To evaluate the financial conditions and liquidity position of companies, this study, uses L - Liquidity in CAMEL model, which captures the predictive viability of the banks' financial performance, by using financial ratios that ultimately predicts a value, which can be used to determine the financial performance of the banking companies. The study concludes that Public Sector Banking Companies are too healthy in terms of liquidity maintenance. The tools applied to measure the liquidity position as per the regulatory authority are effective.

\section{References}

[1] "Fed's Yellen Hardens her stance on banks", Wednesday, August14, 2013, Delhi.Mint, page 20.
[2] TakurRajiv "Bank should wrest control of firms from willful defaulters", Wednesday, August 14,2013, Delhi Mint, page 10.

[3] Diamond D.W, Rajan R.G (2000). A theory of Bank Capital. Journal of Finance 55, 2431-2465.

[4] Berger.A.N, Bouwman C.H.S, (2010). How does Capital effect bank performance during Financial Crisis $<$ http://ssrm.com/abstract 739089>

[5] Sambhav Garg, Priya Jindal \& Dr.Bhavet (2013) "RBI Liquidity heightening threatens to take toll on bank Asset quality", "The Indian Express August 05, 2013".

[6] Guillermo Alger, Ingda Alger (1999), Liquid Assets in Banks: Theory and Practice, www.bc.edu/EC-P/WP446.pdf.

[7] Karthik Srinivasan and Vineet Gupta (2007). Liquidity Management in banks - An Increasingly.

[8] Complex affairs www.icar.in/files/articles/2007-Feb-Liquidity Management in bank.pdf.

[9] Vento G. A, Gang P. L "Bank Liquidity Risk Managementand Supervision: Which ". Journal of Money, Investment andBanking (10), p.79-126, 2009.

[10] FranckR,KrausM, "Liquidity risk and bank portfolioallocation", International Review of Economics and Finance 16,p. 60-77, 2007.

[11] Lev Ratnovski1, "Liquidity and Transparency in Bank RiskManagement", IMF Working Paper January 2013.

[12] Moraine Mohr Griffin, "Liquidity Risk Management AndFinancial Performance In Malaysia: Empirical Evidence FromIslamic Banks", Aceh International Journal of Social Sciences, 1 (2): 68-75 August 2012. 